\title{
PENGARUH PEMASARAN DIGITAL DAN CITRA MEREK TERHADAP KEPUTUSAN PEMBELIAN IN-HOUSE EVENT DI SEMINYAK, BALI
}

\author{
I Nengah Wirata \\ Prodi Manajemen Konvensi dan Perhelatan, Politeknik Pariwisata Bali \\ Jln. Darmaangsa, Kampial, Nusa Dua, Badung, Bali, Indonesia \\ e-mail: wirata@ppb.ac.id
}

\begin{tabular}{l|l|l} 
Received: June, 2021 & Accepted: June, 2021 & Published: July, 2021
\end{tabular}

\begin{abstract}
Through digital marketing, hotels in Seminyak publish their products in the form of in-house events with interesting themes to welcome New Year's Eve. On average they publish it on social media, this aims to facilitate promotion and streamline the time, effort, and costs incurred during the promotion process. The research objective was to examine how digital marketing and brand image influence purchasing decisions at home events in the Seminyak Bali area. The number of samples used was 182 respondents with the purposive sampling technique. Data processing is used with multiple linear regression analysis in the SPSS version 23. The results show that there is a partial positive relationship with digital marketing (X1) 3.151 with a significantly less than the $\alpha$ value $(0.002<0.05)$, brand image of 5.999 with less significance. from the value of $\alpha(0.000<0.05)$ on the purchase decision at the event house in Seminyak, Bali. Simultaneously, digital marketing and brand image have a significant effect on purchasing decisions at home events in the Seminyak Bali area with a value of Fount greater than Fable, namely 98.458> 3.05 and a significance value of 0.000.
\end{abstract}

Keywords: digital marketing, brand image, in-house events

\begin{abstract}
Abstrak
Melalui pemasaran digital, hotel-hotel mempublikasikan produk mereka berupa in house event dengan tema-tema yang menarik untuk menyambut malam pergantian tahun. Ratarata mereka mempublikasikannya di sosial media, ini bertujuan untuk mempermudah promosi dan mengefisienkan waktu, tenaga, dan biaya yang keluar selama berjalannya proses promosi tersebut. Adapun tujuan penelitian adalah untuk mengkaji bagaimana pengaruh pemasaran digital dan citra merek terhadap keputusan pembelian in-house event di Kawasan Seminyak Bali. Jumlah sampel yang digunakan adalah sebanyak 182 responden dengan teknik purposive sampling. Pengolahan data yang digunakan dengan analisis regresi linier berganda pada program SPSS versi 23. Hasil penelitian menunjukkan terdapat hubungan positif secara parsial pemasaran digital (X1) sebesar 3,151, dan citra merek sebesar 5,999 terhadap keputusan pembelian in-house event di Kawasan Seminyak Bali. Secara simultan dari pemasaran digital dan citra merek berpengaruh signifikan terhadap keputusan pembelian in house event di Kawasan Seminyak Bali.
\end{abstract}

Kata Kunci: pemasaran digital, citra merek, in-Hhouse event 


\section{PENDAHULUAN}

Perkembangan pariwisata di Provinsi Bali ini terus meningkat, yang ditandai dengan arus kunjungan wisatawan baik domestik maupun mancanegara. Banyak dari mereka berkunjung tidak hanya pada musim liburan seperti periode Juli dan Agustus. Namun banyak juga yang memilih untuk melakukan perjalanan pada saat event-event tertentu seperti Natal dan Tahun Baru, dimana banyak diselenggarakannya perayaan yang tentunya sangat menyenangkan di malam pergantian tahun. Harga tiket dan akomodasi yang melonjak mahal tidak menyurutkan niat tamu-tamu tersebut untuk menikmati event pergantian malam tahun baru ini di Bali.

Seminyak memiliki akses yang cukup lancar, juga dekat dengan pusat keramaian seperti Pantai Double Six yang sangat popular di kalangan tamu. Banyak café dan restoran sepanjang jalan, juga beach club dan night club, tidak hanya itu, bagi tamu yang enggan keluar hotel karena tidak ingin terjebak macet, bisa menikmati in-house event atau acara yang diadakan hotel di tempat mereka menginap yang biasanya disertakan dengan compulsory dinner di malam tahun baru.

Melihat adanya peluang untuk mendapatkan pendapatan lebih dengan mengadakan in house event pada saat malam tahun baru. Biasanya hotel-hotel sudah menyertakan harga kamar dengan harga compulsory dinner untuk malam tersebut, sehingga tamu mau tidak mau akan menghabiskan waktu di hotel karena sudah membayar untuk harga event tersebut. Di Kawasan Seminyak khususnya, hampir sebagian besar hotel memiliki in house event di malam pergantian tahun, hal tersebut menjadi persaingan bisnis diantara pelaku-pelaku penyedia layanan akomodasi.

Persaingan ketat tersebut dijadikan ajang untuk melakukan promosi besarbesaran di setiap platform sosial media maupun situs web yang biasa disebut dengan pemasaran digital. Hal ini dikarenakan kemajuan teknologi yang sudah memudahkan manusia untuk melakukan transaksi tanpa melalui tatap muka, hanya bermodalkan smartphone informasi apapun bisa didapat dengan mudah termasuk informasi mengenai harga-harga promo untuk liburan tahun baru.

Pemasaran digital dalam prakteknya menggunakan saluran distribusi digital untuk mencapai konsumen dilakukan secara personal dengan biaya yang efekftif. kegiatan pemasaran akan dilakukan secara terus menerus dengan menggunakan media komputer, baik dari penawaran produk, pembayaran dan saluran distribusi produk. Dalam konteks pemasaran, kondisi krisis global membuat banyak organisasi mulai memikirkan dan mencari metode penghematan. Sudah menjadi rahasia umum bahwa biaya terbesar dalam suatu organisasi selalu berasal dari biaya saluran pemasaran dan biaya tenaga kerja . Tidak hanya memanfaatkan pemasaran digital dalam upaya menargetkan pasar, hotel-hotel ini juga menggunakan citra merek dalam memaksimalkan promosinya. Kotler dan Keller (2008) menjelaskan bahwa citra merek merupakan persepsi dan keyakinan yang dilakukan oleh konsumen, seperti tercermin dalam asosiasi yang terjadi dalam memori konsumen. Tjiptono (2005), citra merek merupakan deskripsi tentang asosiasi dan keyakinan konsumen terhadap merek tertentu.

Melalui pemasaran digital, hotelhotel tersebut mempublikasikan produk mereka berupa in house event dengan tema-tema yang menarik untuk menyambut malam pergantian tahun 2020. Rata-rata mereka mempublikasikannya di sosial media, ini bertujuan untuk mempermudah promosi dan mengefisienkan waktu, tenaga, dan biaya yang keluar selama berjalannya proses promosi tersebut. Pihak hotel untuk menjual produknya hanya dengan satu kali unggahan melalui media sosial seperti facebook dan Instagram akan bisa dilihat langsung oleh ribuan bahkan 
jutaan orang. Selain itu media sosial juga dilengkapi dengan fitur periklanan. Dulunya iklan hanya bisa dilakukan melalui televisi, radio dan media cetak, namun pada saat ini sudah banyak ditinggalkan. Kini beralih menjadi pengguna media sosial yang menjadi target untuk iklan tersebut. Melihat kenyataan tersebut, adapun tujuan penelitian ini untuk mengetahui pengaruh pemasaran digital dan citra merek terhadap keputusan pembelian in house event hotel di Kawasan Seminyak Bali.

\section{KAJIAN PUSTAKA}

\subsection{Pemasaran Didital (Digital Marketing)}

Pemasaran digital adalah praktek pemasaran yang menggunakan saluran distribusi digital untuk mencapai konsumen dengan cara yang relevan, personal dan cost-effective (Satyo, 2009). Aktivitas-aktivitas pemasaran akan dilakukan secara intensif menggunakan media komputer, baik mulai dari penawaran produk, pembayaran dan pengirimannya.

Tidak menjadi rahasia umum bahwa biaya terbesar organisasi selalu berasal dari biaya pemasaran dan tenaga kerja (Sanjaya, 2009). Oleh sebab itu organisasi bisnis harus pandai melihat peluang melakukan aktivitas pemasaran yang efektif di era digital dengan biaya yang murah dan efektif. Teknologi digital telah banyak mengubah wajah dunia bisnis, termasuk aktivitas pemasaran. Meskipun pemasaran digital tidak meliputi teknik dan praktek yang masuk dalam kategori internet pemasaran dengan cara-cara untuk mencapai target konsumen yang tidak memerlukan internet (mobile technology). Teknologi telah mengubah cara manusia dalam berbicara, berkomunikasi, bertindak, dan mengambil keputusan. Teknologi telah menjadi sangat efektif dalam memaksimalkan bottom line suatu organisasi.

\subsection{Citra Merek (Brand Image)}

Citra (image) adalah persepsi masyarakat terhadap perusahaan atau produk. Pengertian citra (image) menurut (Kotler, 2009) adalah kepercayaan, ide, dan impresi seseorang terhadap sesuatu. Citra perusahaan menjadi salah satu pegangan bagi konsumen dalam mengambil keputusan penting. Contoh: keputusan untuk membeli suatu barang, keputusan untuk menentukan tempat bermalam, keputusan untuk mengkonsumsi makanan dan minuman, pengambilan kursus, sekolah, dan lain-lain. Citra yang baik akan menimbulkan dampak positif bagi perusahaan, sedangkan citra yang buruk melahirkan dampak negatif dan melemahkan kemampuan perusahaan dalam persaingan.

\subsection{Keputusan Pembelian}

Keputusan pembelian adalah keputusan pembeli tentang merek mana yang dibeli. Konsumen dapat membentuk niat untuk membeli merek yang paling disukai. Keputusan pembelian merupakan suatu proses pengambilan keputusan akan pembelian yang mencakup penentuan apa yang akan dibeli atau tidak melakukan pembelian (Kotler dan Amstrong, 2008).

Setiadi (2003), menyatakan pengambilan keputusan yang diambil oleh konsumen dapat disebut sebagai pemecahan masalah. Dalam proses pengambilan keputusan, konsumen memiliki sasaran atau perilaku mana yang ingin dilakukan untuk mencapai sasaran tersebut. Dengan demikian hal ini dapat membantu memecahkan masalahnya.

Selanjutnya dijelaskan pemecahan masalah merupakan suatu aliran timbal balik yang berkesinambungan diantara faktor lingkungan, proses kognitif dan afektif serta tindakan perilaku. Pada tahap pertama merupakan pemahaman adanya masalah. Selanjutnya terjadi evaluasi terhadap alternatif yang ada dan tindakan yang paling sesuai dipilih. Pada tahap selanjutnya, pembelian dinyatakan 
dalam tindakan yang pada akhirnya barang yang telah dipilih atau ditunjuk akan digunakan dan konsumen akan melakukan evaluasi ulang mengenai keputusan yang telah diambilnya. Pranoto (2008), juga menjelaskan perilaku pengambilan keputusan oleh konsumen untuk melakukan pembelian produk atau jasa diawali dengan adanya kesadaran atas pemenuhan kebutuhan atau keinginan dan menyadari adanya masalah selanjutnya, maka konsumen akan melakukan beberapa tahap yang pada akhirnya sampai pada tahap evaluasi pasca pembelian.

Menurut Assauri (2004) Keputusan pembelian merupakan suatu proses pengambilan keputusan akan pembelian yang mencakup penentuan apa yang akan dibeli atau tidak melakukan pembelian dan keputusan itu diperoleh dari kegiatan-kegiatan sebelumnya. Dari beberapa pengertian pengambilan keputusan yang telah dipaparkan di atas, maka sintesa pendapat dari beberapa sumber bahwa keputusan pembelian adalah suatu proses pengambilan keputusan akan pembelian yang akan menentukan dibeli atau tidaknya pembelian tersebut yang diawali dengan kesadaran atas pemenuhan atau keinginan.

\section{METODE PENELITIAN}

Penelitian ini, untuk mengetahui pengaruh antara variabel bebas dengan variabel terikat, maka analisis regresi linier berganda dipergunakan untuk menganalisis pengaruh variabel independen yaitu pada pemasaran digital dan citra merek terhadap variabel dependen yaitu keputusan pembelian inhouse event hotel di Kawasan Seminyak Bali. Tujuannya adalah untuk mengestimasi nilai rata-rata variabel dependen berdasarkan nilai variabel independen yang sudah diketahui. Daftar pertanyaan disebarkan kepada responden terkait keputusan pembelian in house event hotel di Kawasan Seminyak tahun 2020. Kuesioner disebarkan sebanyak 182 responden yang akan digunakan sebagai sampel untuk penelitian ini.

Penyebaran kuesioner dengan pernyataan-pernyataan disusun dengan lima pilihan, baik yang bersifat positif dengan pilihan lima dan bersifat negatif dengan pilihan satu berskala data ordinal yang menggunakan skala Likert 5 (Sugiyono, 2013:93).

\subsection{Variabel Penelitian}

Indikator untuk mengukur variabel dalam penelitian ini memiliki nilai korelasi yang lebih besar dari 0,1455. Variabel digital marketing (X1), brand image (X2), dan keputusan pembelian inhouse event hotel di Kawasan Seminyak Bali (Y) dengan rhitung ? 0,1455 dan semuanya bernilai positif, sehingga dapat disimpulkan bahwa semua indikator pernyataan yang diujikan adalah valid dan dapat digunakan untuk pengujian selanjutnya. variabel yang dianalisis mempunyai koefisien alpha yaitu di atas 0,60 . Variabel dimensi pemasaran digital (digital marketing) (X1), dan citra merek (brand image) (X2) dan keputusan pembelian in-house event hotel di Kawasan Seminyak Bali (Y) memiliki nilai crombach's alpha lebih dari 0,60. Dapat disimpulkan bahwa kuesioner yang digunakan dalam penelitian ini merupakan kuesioner yang handal dan dapat dipercaya.

Hipotesis pada penelitian:

Ho: $0=0$ Tidak ada pengaruh antara pemasaran digital secara parsial dan simultan terhadap keputusan pembelian in-house event hotel di Kawasan Seminyak Bali

Ho: 00 Tidak ada pengaruh antara citra merek secara parsial dan simultan terhadap keputusan pembelian in-house event hotel di Kawasan Seminyak Bali

Ha: 0 : 0 Ada pengaruh antara
pemasaran digital dan citra
merek secara parsial dan
simultan terhadap keputusan
pembelian in-house event hotel
fi Kawasan Seminyak Bali




\section{HASIL DAN PEMBAHASAN}

\subsection{Karakteristik Responden}

Berdasarkan hasil analisa data dari 182 responden, dapat dilihat dari jenis kelamin bahwa sebagian besar wisatawan mancanegara yang berminat untuk membeli in-house event hotel di Kawasan Seminya Bali adalah dengan jenis kelamin laki-laki, yaitu sebesar $51,1 \%$ dan wanita sebesar 48,9\%, hal tersebut memperlihatkan bahwa laki-laki lebih banyak melakukan aktivitas kegiatan in-house event dibandingkan dengan wanita

Karakteristik

responden

berdasarkan profesi memperlihatkan bahwa sebagian besar responden yang ketertarikan untuk membeli in-house event hotel di Kawasan Seminyak Bali $(66,5 \%)$ mempunyai pekerjaan sebagai pelajar atau mahasiswa. Sebanyak 13,7\% merupakan karyawan swasta dan pemerintah, 9,3\% merupakan wirausaha. Dari seluruh responden 10,5\% wisatawan tidak bekerja, akan tetapi mereka memiliki profesi lain seperti pensiunan, tenaga sukarela, dan bahkan ada yang tidak memiliki pekerjaan.

\subsection{Analisis Regresi Linier Berganda}

Analisis regresi berganda untuk memprediksi nilai pengaruh dua variabel bebas atau lebih terhadap variabel terikat untuk membuktikan ada tidaknya hubungan fungsi atau hubungan kausal antara dua variabel bebas atau lebih dengan satu variabel terikat (Riduwan, 2007:108).

Analisa regresi linier berganda merupakan analisis yang digunakan untuk mengetahui pengaruh variabel pemasaran digital (digital marketing) (X1), dan citra merek (brand image) (X2) terhadap keputusan pembelian in-house event di Kawasan Seminyak Bali (Y).

Berdasarkan hasil analisis data, maka dapat dilihat bentuk persamaan regresi linier berganda yaitu pemasaran digital (digital marketing) dan citra merek (brand image) terhadap keputusan pembelian in-house event hotel di
Kawasan Seminyak Bali dapat dituliskan sebagai berikut:

$\mathrm{Y}=0,229+0,255 \mathrm{X} 1+0,230 \mathrm{X} 2$

Interpretasi dari persamaan regresi tersebut adalah:

1) Nilai konstanta sebanyak 0,229 artinya jika variabel pemasaran digital dan citra merek ditiadakan maka keputusan pembelian in house event bernilai sebanyak 0,229. Bila nilai variabel bebas (pemasaran digital dan citra merek) meningkat, maka variabel terikat (keputusan pembelian in house event) akan mengalami peningkatan.

2) Nilai koefisien regresi variabel pemasaran digital terhadap keputusan pembelian in house event sebanyak 0,255 artinya jika pemasaran digital mengalami kenaikan sebesar satu satuan, sementara variabel lainnya tetap maka keputusan pembelian in house event akan mengalami peningkatan sebesar 0,255. Koefisien pemasaran digital bernilai positif artinya antara pemasaran digital (digital marketing) dan keputusan pembelian in house event memiliki hubungan positif. Peningkatan pemasaran digital akan mengakibatkan peningkatan pada keputusan pembelian in house event hotel di Kawasan Seminyak Bali.

3) Nilai koefisien regresi variabel citra merek (brand image) terhadap keputusan pembelian in house event sebanyak 0,230 artinya jika citra merek mengalami kenaikan sebesar satu satuan, sementara variabel lainnya tetap maka keputusan pembelian in house event akan mengalami peningkatan sebesar 0,230 . Koefisien citra merek bernilai positif artinya antara citra merek (brand image) dan keputusan pembelian in house event memiliki hubungan positif. Kenaikan citra merek (brand image) akan mengakibatkan kenaikan pada keputusan pembelian in house event hotel di Kawasan Seminyak Bali. 
Uji $\mathrm{F}$ dilakukan untuk mengetahui pengaruh varibel pemasaran digital (digital marketing) (X1), dan citra merek (brand image) (X2) terhadap keputusan pembelian in-house event hotel di Kawasan Seminyak Bali (Y). Pengaruh keseluruhan variabel secara simultan akan dilihat dari besarnya nilai Fhitung yang didapatkan dan kemudian dibandingkan dengan Ftabel. Berdasarkan hasil nilai Ftabel yaitu 3,05 dan nilai Fhitung yaitu 98,458. Nilai Fhitung > Ftabel $(98,458>3,05)$ dan signifikan Fhitung 0 0,05 (0,000 0 0,05), maka Ho ditolak dan Ha diterima.

\subsection{Analisis Koefisien Detreminasi (R2)}

Berdasarkan hasil yang diperoleh dengan bantuan SPSS versi 23, maka didapatkan nilai adjusted R square (R2) adalah 0,525. Dari nilai tersebut dihitung koefisien determinasinya yaitu $0,525 \mathrm{x}$ $100 \%=52,5$ persen. Dari hasil tersebut diketahui bahwa pemasaran digital dan citra merek secara bersama-sama mempengaruhi keputusan pembelian inhouse event hotel di Kawasan Seminyak Bali sebesar 52,5 persen dikatagorikan sedang, selebihnya yaitu 47,5 persen merupakan keputusan pembelian inhouse event hotel di Kawasan Seminyak Bali yang dipengaruhi oleh faktor-faktor lain yang tidak diteliti.

\section{KESIMPULAN}

Berdasarkan pada hasil penelitian yang telah dilakukan, dapat disimpulkan sebagai berikut:

a) Terdapat hubungan positif antara pemasaran digital dan citra merek terhadap keputusan pembelian inhouse event hotel secara parsial di Kawasan Seminyak Bali. Hubungan antara variabel pemasaran digital terhadap keputusan pembelian inhouse event memiliki hubungan yang sedang dengan nilai koefisien korelasi sebesar 0,255. Hubungan antara citra merek terhadap keputusan pembelian in-house event memiliki hubungan yang sedang dengan nilai koefisien sebesar 0,230.

b) Terdapat hubungan positif antara pemasaran digital dan citra merek terhadap keputusan pembelian inhouse event secara simultan di Kawasan Seminyak Bali. Hubungan antara variabel pemasaran digital dan citra merek terhadap keputusan pembelian in-house event memiliki hubungan yang kuat dengan nilai koefisien korelasi sebesar 0,725.

c) Terdapat hubungan positif signifikan yang kuat antara pemasaran digital dan citra merek terhadap keputusan pembelian in-house event di Kawasan Seminyak Bali. Secara parsial pemasaran digital (thitung > ttabel $/ 3,151>1,653$ ), dan citra merek (thitung > ttabel/ 5,999 > 1,653). Pemasaran digital dan citra merek juga berpengaruh secara simultan terhadap keputusan pembelian in-house event hotel di Kawasan Seminyak Bali (Fhitung > Ftabel $/ 98,458>3,05$ ). Analisa ini juga menunjukkan bahwa pemasaran digital dan citra merek berpengaruh secara signifikan dan searah terhadap keputusan pembelian inhouse event hotel di Kawasan Seminyak Bali.

\section{DAFTAR PUSTAKA}

Adyanto, C. \& Santosa, S.B (2018) Pengaruh kualitas layanan, brand image, harga dan kepercayaan produk terhadap keputusan pembelian (Studi layanan Ecommerce

Berrybenka.com),Diponegoro Journal of Management, vol. 7, no. 1, pp. 1029, Jun. 2018. [Online].

Assauri, S. (2004). Manajemen Pemasaran. Jakarta: Rajawali Press.

Fitrianna, (2020). Pengaruh Digital Marketing Pada Peningkatan Brand Awarness dan Brand Image Terhadap keputusan Pembelian Produk Cokelat Monggo di Yogyakarta. Jurnal Inovasi Bisnis dan Manajemen Indonesia Universitas 
Negeri Yogyakarta, Vol. 03, No. 03, Juni 2020. P. 409-418.

Heriyati, P., \& Septi, S. (2012). Analisis pengaruh brand image dan kualitas produk terhadap keputusan pembelian konsumen pada handphone nexian. Journal of Business Strategy and Execution, 4(2), 171 - 205. Retrieved from https://journal.binus.ac.id/ index.php/JBSE/article/view/275

Kotler, P. (2009). Manajemen Pemasaran 1.Edisi ketiga belas. Jakarta: Erlangga

Kotler, P. \& Armstrong, G. (2008). Prinsip-prinsip pemasaran, jilid I. Jakarta: Erlangga.

Kotler, P. dan Keller, K.L. (2008). Manajemen Pemasaran Jilid 2. Edisi Kedua Belas. Jakarta: PT. Indeks.

Leksono, R., \& Herwin, H. (2017). Pengaruh harga dan promosi grab terhadap brand image yang mempengaruhi keputusan pembelian konsumen pengguna transportasi berbasis online. Jurnal Riset Manajemen Dan Bisnis (JRMB) Fakultas Ekonomi UNIAT, 2(3), 381390.

https://doi.org/10.36226/jrmb.v2i3. 72

Pranoto, S. (2008). Analisis Indeks Keberlanjutan Industri Kecil Dan Menengah di Kabupaten Bogor, Skripsi, Fakultas Teknologi Pertanian, Institut Pertanian Bogor, Bogor.

Sanjaya, W. (2009). Strategi Pembelajaran Berorientasi Standar Proses pendidikan.Kencana. Jakarta.

Fatwan, S. (2009). Intellectual Capital. Jakarta: Gramedia Pustaka Utama.

Setiadi, N.J. (2003). Perilaku Konsumen : Konsep dan Implikasi Untuk Strategi dan Penelitian Pemasaran. Jakarta : Kencana

Tjiptono, F. (2005). Strategi Pemasaran Edisi 3. Yogyakarta: Andi

Riduwan (2007). Pengantar Statistika. Bandung: Alfabeta.

Sugiyono. 2013. Metode penelitian Kuantitatif, Kualitatif dan R\&D. Bandung: Alfabeta.
Suryani, S. \& Rosalina, S. S. (2019) Pengaruh brand image, brand trust, dan kualitas layanan terhadap keputusan pembelian ulang dengan kepuasan konsumen sebagai variabel moderating pada startup business unicorn Indonesia. Journal of Business Studies. Vol 4, No 1

Wiranata, dkk. (2021). Pengaruh Digital Marketing, Quality Product dan Brand Image Terhadap Keputusan Pembelian Roti di Holland Bakery Batubulan. Jurnal Emas, Fakultas Ekonomi Universitas Mahasaraswati. Vol. 2 No.3 Maret 2021. P.133-1 